\title{
ANALISIS PERBANDINGAN HASIL PEMERIKSAAN KREATININ DARAH DENGAN DEPROTEINISASI DAN NONDEPROTEINISASI METODE JAFFE REACTION
}

\author{
Sitti Hadijah \\ Jurusan Analis Kesehatan Poltekkes Kemenkes Makassar \\ shitaku2975@gmail.com
}

\begin{abstract}
ABSTRAK
Di berbagai RS pemeriksaan cepat sangat diperlukan untuk efesiensi waktu. Cara nondeproteinisasi merupakan cara yang paling sering digunakan. Selain faktor ekonomis, cara nondeproteinisasi lebih mudah digunakan. Kekurangan dari metode ini adalah beberapa protein tidak diendapkan sehingga dapat menyebabkan tinggi palsu pada kreatinin.Untuk itu perlu adanya penambahan zat yang dapat mengendapkan protein tersebut. Salah satu cara yang dapat digunakan yaitu cara deproteinisasi. Tujuan dari penelitian ini untuk menentukan perbedaan hasil pemeriksaan kreatinin darah dengan deproteinisasi dan nondeproteinisasi metode jaffe reaction.Jenis penelitian yang digunakan adalah Observasi analitik study komparatif.Sampel penelitian adalah 15 penderita gagal ginjal di Rumah Sakit Islam Faisal Makassar pada tanggal 3-9 April 2017. Hasil pemeriksaan kreatinin darah metode jaffe reaction didapatkan nilai tertinggi cara deproteinisasi $20 \mathrm{mg} / \mathrm{dl}$ dan nilai terendah $4,8 \mathrm{mg} / \mathrm{dl}$, nilai rata-ratanya $9.793 \mathrm{mg} / \mathrm{dl}$ dan standar deviasi sebesar $3.7003 \mathrm{mg} / \mathrm{dl}$, sedangkan cara nondeproteinisasi didapatkan nilai tertinggi $20.3 \mathrm{mg} / \mathrm{dl}$ dan nilai terendah $5.7 \mathrm{mg} / \mathrm{dl}$, nilai rata-ratanya $10.453 \mathrm{mg} / \mathrm{dl}$ dan standar deviasi sebesar $3.5689 \mathrm{mg} / \mathrm{dl}$. Setelah dilakukan uji T dua sampel berpasangan didapatkan hasil yang menunjukkan bahwa $\mathrm{T}$ hitung<T tabel $(0.497<1.753)$ hal tersebut menunjukkan bahwa tidak ada perbedaan yang signifikan antara kedua cara tersebut.

Kata Kunci: Kreatinin Darah, Deproteinisasi, Nondeproteinisasi, Metode Jaffe Reaction
\end{abstract}

\section{PENDAHULUAN}

Perkembangan penyakit dalam semakin berkembang setiap tahunnya, baik dari perkembangan jenis penyakitnya maupun jumlah penderitanya.Penyakit dalam adalah suatu penggolongan penyakit di dalam dunia kedokteran yang mempunyai ragam penyakit yang paling banyak dan sampai saat ini penggolongannya masih terus berlangsung.Salah satu yang termasuk penyakit dalam adalah gagal ginjal (Sulistyowati I, 2011).
Gagal ginjal merupakan kondisi dimana ginjal tidak mampu menjalankan fungsinya untuk mempertahankan homeostatis dalam mengatur volume cairan, keseimbangan osmotik, asam basa, ekskresi sisa metabolisme dan sistem pengaturan hormonal (Syaifuddin, 2009)

Menurut data dari The United States Renal Data System (USRDS) tahun 2009 Penyakit Ginjal Kronik (PGK) tahap akhir sering ditemukan dan 
prevalensinya sekitar 10 sampai $13 \%$. Di Amerika Serikat jumlahnya mencapai 25 juta jiwa, dan di Indonesia diperkirakan $12,5 \%$ atau sekitar 18 juta jiwa (Pratama dkk, 2014).

Di Indonesia survei persatuan ahli penyakit dalam pada tahun 1990 sampai 1992 menunjukkan bahwa $13 \%$ dari 50.000 pasien rawat inap dirumah sakit yang ada diseluruh Indonesia menderita gagal ginjal dan menempati urutan ke 4 setelah tifoid, tuberkulosis paru dan enteritis.Pada bulan Maret sampai Mei 2001, di RS Dr Wahidin Sudirohusodo, telah dilakukan suatu penelitian "Gambaran Urinalisis Gagal Ginjal Kronik di RSUP Dr. Wahidin Sudirohusodo Makassar" dan didapatkan hasil dari 116 orang yang memeriksakan kadar kreatinin urin dengan rumus Cockroft dan Gault didapatkan hasil sebanyak 109 orang $(93,97 \%)$ menderita gagal ginjal dan 7 orang $(6,03 \%)$ menderita gagal ginjal kronik (Hardjoeno, 2007).

Kreatinin adalah produk akhir dari metabolisme kreatin.Kreatinin terutama disintesis oleh hati, tedapat hampir semuanya dalam otot rangka yang terikat secara reversible dengan fosfat dalam bentuk fosfokreatin atau keratinfosfa, yakni senyawa penyimpan energi.Pemeriksaan kreatinin dalam darah merupakan salah satu parameter penting untuk mengetahui fungsi ginjal.Pemeriksaan ini juga sangat membantu kebijakan melakukan terapi pada penderita gangguan fungsi ginjal. Tinggi rendahnya kadar kreatinin dalam darah digunakan sebagai indikator penting dalam menentukan apakah seorang dengan gangguan fungsi ginjal memerlukan tindakan hemodialysis (Alfonso, 2016).
Pemilihan metode yang tepat juga banyak membantu dalam melakukan pemeriksaan. Ada beberapa cara yang digunakan dalam

Pemeriksaan kreatinin dalam darah yakni cara deprotoeinisasi dan nondeproteinisasi. Ada beberapa keuntungan pengukuran kreatinin cara deproteinisasi diantaranya kandungan nitrogen dalam sampel seperti protein, dan ureum sudah terikat dengan Trichlor Acetic Acid (TCA) sehingga supernatan terbebas dari bahan-bahan nitrogen akan tetapi sampel yang dibutuhkan cukup banyak sedangkan beberapa keuntungan kreatinin cara nondeproteinisasi yakni, waktu yang diperlukan cukup singkat dan sampel yang diperlukan hanya sedikit.

Cara nondeproteinisasi merupakan cara yang paling sering digunakan. Selain faktor ekonomis, cara nondeproteinisasi lebih mudah digunakan. Namun kekurangan dari metode ini adalah beberapa protein tidak diendapkan sehingga dapat menyebabkan tinggi palsu pada kreatinin.Untuk itu perlu adanya penambahan zat yang dapat mengendapkan protein tersebut. Salah satu cara yang dapat digunakan yaitu cara deproteinisasi.

Tujuan penelitian ini adalah untuk mengetahui perbandingan hasil pemeriksaan kreatinin darah dengan cara deproteinisasi dan nondeproteinisasi menggunakan metode Jaffe Reaction

\section{METODE}

Metode yang digunakan adalah Observasi analitik dengan study komparatif.Sampel adalah penderita gagal ginjal sebanyak 15 orang, menggunakan teknik purposive sampling.Lokasi penelitian 
dilaksanakan dilaboratorium RS Islam Faisal Makassar.

Data telah diperoleh berdasarkan hasil pemeriksaan laboratorium. Hasil penelitian ini dianalisa menggunakan uji T dua sampel berpasangan.

Prosedur kerja untuk cara Deproteinisasi, serum dipipet sebanyak $500 \mu 1$ kedalam tabung reaksi kemudian ditambahkan $500 \mu 1$ reagen standar, $500 \mu \mathrm{l}$ aquades dan $500 \mu 1$ reagen TCA lalu disentrifuse selama 10 menit dengan kecepatan 3000rpm. Selanjutnya $500 \mu 1$ supernatant ditambahkan $500 \mu 1$ asam pikrat dan $\mathrm{NaOH}$ dengan perbandingan 1:1, dihomogenkan dan diinkubasi selama 30 menit. Selanjutnya diperiksa menggunakan fotometer 5010. Sedangkan untuk metode Nondeproteinasi, serum dipipet sebanyak $100 \mu \mathrm{l}$ dan ditambahkan reagen standar $100 \mu 1$ dan $1000 \mu 1$ asam pikrat dan $\mathrm{NaOH}$ dengan perbandingan 1:1 kemudian dihomogenkan dan diinkubasi selama 2 menit. Selanjunya diperiksa menggunakan fotometer 5010 dengan panjang gelombang $492 \mathrm{~nm}$.

\section{HASIL}

Penelitian ini dilaksanakan di Laboratorium RS Islam Faisal Makassar. Selama penelitian didapatkan 15 sampel darah penderita gagal ginjal.

Hasil pemeriksaan kadar kreatinin darah dengan deproteinisasi dan nondeproteinisasi metode jaffe reaction pada penderita gagal ginjal dapat dilihat pada tabel 1 berikut ini.

Tabel 1 Hasil pemeriksaan kadar kreatinin darah dengan deproteinisasi dan nondeproteinisasi metode Jaffe Reaction

\begin{tabular}{|c|c|c|c|}
\hline \multirow{2}{*}{$\begin{array}{c}\text { NO } \\
\text { SAMPEL }\end{array}$} & \multirow{2}{*}{$\begin{array}{c}\text { JENIS } \\
\text { KELAMIN }\end{array}$} & \multicolumn{2}{|c|}{ HASIL PEMERIKSAAN } \\
\hline & & NONDEPROTEINISASI & DEPROTEINISASI \\
\hline 1 & $\mathrm{P}$ & $11.4 \mathrm{mg} / \mathrm{dl}$ & $10.8 \mathrm{mg} / \mathrm{dl}$ \\
\hline 2 & $\mathrm{~L}$ & $20.3 \mathrm{mg} / \mathrm{dl}$ & $20 \mathrm{mg} / \mathrm{dl}$ \\
\hline 3 & $\mathrm{P}$ & $7.1 \mathrm{mg} / \mathrm{dl}$ & $6.3 \mathrm{mg} / \mathrm{dl}$ \\
\hline 4 & $\mathrm{P}$ & $10.4 \mathrm{mg} / \mathrm{dl}$ & $9.7 \mathrm{mg} / \mathrm{dl}$ \\
\hline 5 & $\mathrm{P}$ & $6.7 \mathrm{mg} / \mathrm{dl}$ & $5.9 \mathrm{mg} / \mathrm{dl}$ \\
\hline 6 & $\mathrm{~L}$ & $10.1 \mathrm{mg} / \mathrm{dl}$ & $9.4 \mathrm{mg} / \mathrm{dl}$ \\
\hline 7 & $\mathrm{P}$ & $9.6 \mathrm{mg} / \mathrm{dl}$ & $8.9 \mathrm{mg} / \mathrm{dl}$ \\
\hline 8 & $\mathrm{~L}$ & $12.8 \mathrm{mg} / \mathrm{dl}$ & $12 \mathrm{mg} / \mathrm{dl}$ \\
\hline 9 & $\mathrm{P}$ & $7.0 \mathrm{mg} / \mathrm{dl}$ & $6.3 \mathrm{mg} / \mathrm{dl}$ \\
\hline 10 & $\mathrm{~L}$ & $5.7 \mathrm{mg} / \mathrm{dl}$ & $4.8 \mathrm{mg} / \mathrm{dl}$ \\
\hline 11 & $\mathrm{~L}$ & $12.4 \mathrm{mg} / \mathrm{dl}$ & $11.8 \mathrm{mg} / \mathrm{dl}$ \\
\hline 12 & $\mathrm{~L}$ & $8.3 \mathrm{mg} / \mathrm{dl}$ & $7.6 \mathrm{mg} / \mathrm{dl}$ \\
\hline 13 & $\mathrm{~L}$ & $12.1 \mathrm{mg} / \mathrm{dl}$ & $11.6 \mathrm{mg} / \mathrm{dl}$ \\
\hline 14 & $\mathrm{P}$ & $10.7 \mathrm{mg} / \mathrm{dl}$ & $10 \mathrm{mg} / \mathrm{dl}$ \\
\hline 15 & $\mathrm{P}$ & $12.2 \mathrm{mg} / \mathrm{dl}$ & $11.8 \mathrm{mg} / \mathrm{dl}$ \\
\hline
\end{tabular}

Sumber : Data Primer, 2107 
Sesuai dengan tujuan penelitian ini yaitu untuk mengetahui perbandingan kadar kreatinin darah dengan cara deproteinisasi dan nondeproteinisasi metode jaffe reaction, maka selanjutnya dilakukan pengujian standar deviasi dan standar error untuk mengetahui seberapa besar perbandingan nilai sampel terhadap rata-ratanya yang dapat dilihat pada tabel 2 berikut

Tabel 2 Standar deviasi dan standar error

\begin{tabular}{|c|c|c|c|c|c|}
\hline \multicolumn{7}{|c|}{ Group Statistics } \\
\hline & Kelompok & $\mathrm{N}$ & Mean & $\begin{array}{c}\text { Std.Deviati } \\
\text { on }\end{array}$ & $\begin{array}{c}\text { Std.Erro } \\
\text { r Mean }\end{array}$ \\
\hline \multirow{2}{*}{ Nilai } & Nondeproteinisasi & 15 & 10.453 & 3.5689 & .9215 \\
\cline { 2 - 6 } & Deproteinisasi & 15 & 9.793 & 3.7003 & .9554 \\
\hline
\end{tabular}

Sumber : Output SPSS 24

Dari 15 sampel hasil pemeriksaan kreatinin darah dengan cara nondeproteinisasi diperoleh nilai rata - rata adalah $10.453 \mathrm{mg} / \mathrm{dl}$, dengan standar deviasi sebesar $3.5889 \mathrm{mg} / \mathrm{dl}$ dan standar error sebesar $9215 \mathrm{mg} / \mathrm{dl}$ sedangkan nilai rata-rata dari cara deproteinisasi adalah $9.793 \mathrm{mg} / \mathrm{dl}$, dengan standar deviasi sebesar $3.7003 \mathrm{mg} / \mathrm{dl}$ dan standar error $9.554 \mathrm{mg} / \mathrm{dl}$. Dari hasil tersebut kemudian dilakukan pengujian hipotesa menggunakan uji $\mathrm{T}$ dua sampel berpasangan untuk mengetahui perbandingan antara pemeriksaan kadar kreatinin darah menggunakan cara deproteinisasi dan nondeproteinisasi metode jaffe reaction yang dapat dilihat pada tabel .3 berikut ini.

Tabel 3 Uji T dua sampel berpasangan

\begin{tabular}{|c|c|c|c|c|c|c|c|c|c|c|}
\hline \multicolumn{11}{|c|}{ Independent Samples Test } \\
\hline & & \multicolumn{2}{|c|}{$\begin{array}{l}\text { Levene's Test } \\
\text { for Equality of } \\
\text { Variances }\end{array}$} & \multicolumn{7}{|c|}{ t-test for Equality of Means } \\
\hline & & \multirow[t]{2}{*}{$\mathrm{F}$} & \multirow[t]{2}{*}{ Sig. } & \multirow[t]{2}{*}{$\mathrm{t}$} & \multirow[t]{2}{*}{ df } & \multirow[t]{2}{*}{$\begin{array}{l}\text { Sig. (2- } \\
\text { tailed) }\end{array}$} & \multirow{2}{*}{$\begin{array}{c}\text { Mean } \\
\text { Differenc } \\
\mathrm{e}\end{array}$} & \multirow{2}{*}{\begin{tabular}{|c|} 
Std. \\
Error \\
Differenc \\
e \\
\end{tabular}} & \multicolumn{2}{|c|}{$\begin{array}{l}\text { 95\% Confidence } \\
\text { Interval of the } \\
\text { Difference }\end{array}$} \\
\hline & & & & & & & & & Lower & Upper \\
\hline nilai & $\begin{array}{c}\text { Equal } \\
\text { variances } \\
\text { assumed }\end{array}$ & .011 & .917 & .497 & 28 & .623 & .6600 & 1.3274 & -2.0590 & 3.3790 \\
\hline \multicolumn{11}{|c|}{ Sumber: Output SPSS 24} \\
\hline \multicolumn{11}{|c|}{$\begin{array}{llll}\text { berpasangan menunjukkan bahwa } \mathrm{T} & \text { nondeproteinisasi } & \text { metode } & \text { jaffe } \\
\text { hitung }>\mathrm{T} \text { table }(0.497<1,753) \text { maka } & \text { reaction. }\end{array}$} \\
\hline
\end{tabular}

Ho diterima berarti tidak ada perbedaan yang signifikan antara 


\section{PEMBAHASAN}

Kreatinin adalah produk akhir dari metabolisme kreatin. Kreatinin terutama disintesis oleh hati, tedapat hampir semuanya dalam otot rangka yang terikat secara reversible dengan fosfat dalam bentuk fosfokreatin atau keratinfosfa, yakni senyawa penyimpan energi (Alfonso,2006).

Salah satu pemeriksaan yang mencerminkan terjadinya gangguan fungsi ginjal adalah pemeriksaan Kreatinin.Pemeriksaan kreatinin berguna untuk mengevaluasi fungsi dari glomerulus yang hasilnya lebih spesifik. Peningkatan kadar kreatinin menunjukkan indikasi penyakit ginjal atau kerusakan nefron lebih dari 50\% (Soewoto H,dkk, 2001 ).

Ada 2 cara yang digunakan dalam pemeriksaan kreatinin dalam darah yakni cara deprotoeinisasi dan nondeproteinisasi. Ke 2 cara ini juga mempunyai kelebihan dan kekurangan. Kelemahan pemeriksaan kreatinin cara deproteinisasi adalah Trichlor acetic acid (TCA) terlalu pekat, Konsentrasi TCA salah apabila menggunakan TCA $3 \mathrm{~N}$, waktu inkubasi yang diperlukan terlalu lama yaitu 30 menit dan sampel yang diperlukan telalu banyak serta TCA pada suhu kamar mudah terurai maka penyimpanannya di lemari es $( \pm 2$ $8^{\circ} \mathrm{C}$ ) Adapun keuntungan dari pemeriksaan kreatinin cara deproteinisasi adalah Kandungan nitrogen dalam sampel seperti protein, ureum, dll sudah terikat dengan TCA sehingga supernatan terbebas dari bahan-bahan nitrogen.

Kelemahan pemeriksaan kreatinin cara nondeproteinisasi adalah pencampuran reagen kerja tidak dengan perbandingan 1:1 akan mengakibatkan hasil tinggi palsu serta adanya gangguan terhadap hasil pemeriksaan kreatinin darah oleh bilirubin, ureum, protein yang tidak diendapkan dengan TCA. Adapun Kelebihan pemeriksaan kreatinin cara nondeproteinisasi adalah waktu yang diperlukan cukup singkat (2menit) dan sampel yang diperlukan hanya sedikit (100 $\mu \mathrm{l})$.

Metode yang sering digunakan untuk pemeriksaan kreatinin darah adalah metode Jaffe Reaction yang merupakan salah satu metode dimana pengujian kadar kreatininnya menggunakan asam pikrat yang berperan untuk mengikat kreatinin sehingga menciptakan warna kuning.

Berdasarkan hasil penelitian dari 15 sampel diperoleh bahwa hasil pemeriksaan kreatinin darah metode jaffe reaction didapatkan nilai tertinggi cara deproteinisasi $20 \mathrm{mg} / \mathrm{dl}$ dan nilai terendah $4,8 \mathrm{mg} / \mathrm{dl}$, nilai rata-ratanya $9.793 \mathrm{mg} / \mathrm{dl}$ dan standar deviasi sebesar $3.7003 \mathrm{mg} / \mathrm{dl}$ sedangkan cara nondeproteinisasi didapatkan nilai tertinggi $20.3 \mathrm{mg} / \mathrm{dl}$ dan nilai terendah $5.7 \mathrm{mg} / \mathrm{dl}$, nilai rata-ratanya $10.453 \mathrm{mg} / \mathrm{dl}$ dan standar deviasi sebesar $3.5689 \mathrm{mg} / \mathrm{dl}$ . Setelah dilakukan uji T dua sampel berpasangan didapatkan hasil yang menunjukkan bahwa $\mathrm{T}$ hitung $<\mathrm{T}$ tabel $(0.497<1.753)$ hal tersebut menunjukkan bahwa tidak ada perbedaan yang signifikan antara kedua cara tersebut. Hasil ini didukung oleh penelitian sebelumnya yang dilakukan oleh Kus W (2010) yang menyatakan tidak ada perbedaan yang signifikan antara cara deproteinisasi dan nondeproteinisasi (Kus, 2010) 


\section{KESIMPULAN}

Berdasarkan hasil penelitian yang telah dilakukan, dapat disimpulkan bahwa tidak ada perbedaan yang signifikan antara hasil pemeriksaan kreatinin darah cara deproteinisasi dan nondeproteinisasi metode Jaffe reaction. Disarankan peneliti berikutnya sebaiknya sampel yang digunakan diperbanyak.

\section{DAFTAR PUSTAKA}

Hardjoeno H, 2007. Interpretasi Hasil Tes Laboratorium Diagnostik. Makassar: Universitas Hasanuddin (LEPHAS)

Kus W, 2010, perbandingan Hasil Pemeriksaan Kreatinin Darah Metode Jaffe Reaction Cara Deproteinisasi dan Nondeproteinisasi.

http://digilib.unimus.ac.id, diakses 10 Juni 2017

Pratama A, Moeis E.S dan Mandang V, 2014. Hubungan Produk Ca X dengan Kadar C-Terminal Cross Linking Telopeptide Type 1 Collagen pada Subjek Penyakit Ginjal Kronik yang menjalani Hemodialisa Rutin, Jurnal eclinic (eCl), Volume 2, Nomor 3, November 2014. http://ejournal.unsrat.ac.id/index .php/eclinic/article/view/5744/52 77. diakses 10 Januari 2017

Sulistyowati I, 2011.Implementasi Sistem Pakar Berbasis Web Untuk Mendiagnosis Penyakit Dalam Pada Manusia. http://publikasi.dinus.ac.id/index .php/semantik/article/view/113/7 0, diakses 18 januari 2017
Soewoto H, Sadikin M, Kurniati V, Inawati SW, Retno DG, Abadi P, Prijayanti AR, Harahap IP dan Widia SA, 2001, Biokimia Eksperimen Laboratorium. Jakarta : Widya Medika

Suandi, 2000. Diit Pada Anak Sakit. Jakarta : Buku Kedokteran EGC

Syaifuddin, 2009. Anatomi Tubuh Manusia. Jakarta: Salemba Medika 